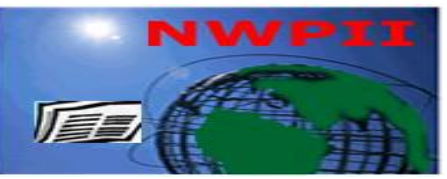

American Journal of Biomedical Sciences

ISSN: 1937-9080

nwpii.com/ajbms

\title{
CD4+T Cells and Tumor Necrosis Factor Alpha in Subjects Living with Human Immunodeficiency Virus in Ekiti State, Nigeria
}

\author{
Oluboyo A. O*, Oluwatayo K. J, Oluboyo B.O
}

Department of Medical Laboratory Science, College of Medicine and Health Sciences, Afe Babalola University, Ado Ekiti, Ekiti State, Nigeria.

"Corresponding Author

Dr A.O Oluboyo

Department of Medical Laboratory Science

College of Medicine and Health Sciences

Afe Babalola University, Ado Ekiti

Ekiti State

Nigeria

Phone Number: +2348062549343

Email: oluboyoao@abuad.edu.ng

Received:30 March 2020; $\mid$ Revised:15 April 2020; $\mid$ Accepted:06 June 2020

\section{Abstract}

Human immunodeficiency virus/Acquired immunodeficiency syndrome (HIV/AIDS) is a global pandemic disease with incidence in every country of the world. People living with HIV are prone to developing inflammatory diseases. Thus, the study aimed to assess the level of CD4+ T cells and tumor necrosis factor alpha (TNF- a ) in HIV subjects relative to control. A total of 92 subjects (46 HIV positive subjects and 46 apparently healthy subjects without HIV) between the ages of 30-75 years were investigated. The subjects were grouped based on age, antiretroviral therapy and gender. CD4 $+\mathrm{T}$ cells were estimated using flow cytometer and TNF- a was estimated using enzyme linked immunosorbent assay. The results obtained showed that there was significant decrease in the levels of CD4+ T cells $(p<0.001)$ and TNF- $\alpha$ $(\mathrm{p}<0.05)$ of HIV subjects compared with apparently healthy subjects (control). The study concluded that the decreased level of CD4+ T cells in HIV seropositive subjects could create an opportunity for opportunistic infections which could cause inflammation and in turn raise the level of TNF- $\alpha$ in the body. Therefore, there is need to monitor these parameters during HIV infection.

Keywords: TNF- a , CD4, HIV, ART

\section{Introduction}

HIV/AIDS is a global pandemic disease with incidence in every country of the world ${ }^{[1]}$. It has been shown that approximately 36.9 million people are living with HIV globally and about 940,000 died from AIDS in $2017^{[2]}$. It may be sexually transmitted by contact with or transfer 
of blood, pre-ejaculate, semen, and vaginal fluids. Research has shown (for both same-sex and opposite-sex couples) that HIV is not transmissible through sexual intercourse if the HIV-positive partner has a consistently undetectable viral load ${ }^{[3]}$. Non-sexual transmission can occur from an infected mother to her infant during pregnancy, during childbirth by exposure to her blood or vaginal fluid, and through breast milk ${ }^{[4,5]}$. Over time, HIV can destroy many cells of the body especially the immune cells such that it cannot fight off infections and other diseases. The damage to the immune system makes it easy for opportunistic infections or cancer to take advantage of the weak immune system thereby making the person to progress to developing AIDS which was first recognized among homosexual men in the United States (US) in $1981^{[6,7]}$.

Within a few weeks of HIV infection, the virus begins a massive assault on the gut, which undergoes a significant depletion of memory CD4+ $\mathrm{T}$ cells. Such depletion is followed by disruption of the tight junctions in the intestinal epithelium, which may not be fully restored even with early antiretroviral therapy (ART) initiation ${ }^{[8,9]}$. The persistent inflammation also affects the functionality of the thymus, which is necessary for the achievement of complete immune recovery. In untreated adults, HIV infection causes chronic inflammation and immune activation that induce thymopoiesis, leading to long term thymic dysfunction and clonal exhaustion of $\mathrm{T}$ cells, which when persistent can also lead to other infections such as hepatitis, cytomegalovirus, and Epsteinbarr virus ${ }^{[10]}$.

Tumor necrosis factor-alpha (TNF- $a$ ) is one of the most important proinflammatory cytokines and has been shown to perform diverse functions. It is primarily produced in the peripheral cells including activated monocytes or macrophages [11]. Earlier reports demonstrated that TNF- a stimulated HIV replication in a variety of cells and that its mRNA levels were higher in HIV-seropositive compared to uninfected brain tissue ${ }^{[12,13]}$. It has also been shown that TNF- a alone or in synergy with other cytokines may upregulate HIV replication and production in host cells ${ }^{[14,15]}$. Thus, the research was set to assess the level of CD4+ $\mathrm{T}$ cells and
TNF- a in HIV seropositive subjects in Ekiti State, Nigeria.

\section{Materials and Methods}

The subjects were recruited from Federal Medical Centre, Ido-Ekiti and its immediate environments in Ekiti State. Ethical clearance was obtained from Federal Medical Center, Ido-Ekiti, Ekiti State. The subjects' consents were sought and obtained before blood specimens were collected from them and voluntary participation was ensured. The subjects included males and females who are HIV seropositive, HIV seropositive subjects who were on ART and apparently healthy subjects which served as control. Individuals who have cardiovascular diseases and all other disease conditions were excluded from this study. The samples collected were used for estimation of CD4 $+\mathrm{T}$ cells and TNF- $\alpha$.

\section{Determination of parameters}

Estimation of TNF-alpha was carried out using Enzyme linked immunoassay (ELISA) technique ${ }^{[16]}$ while estimation of $\mathrm{CD} 4+\mathrm{t}$ cells was done using the principle of flow cytometry ${ }^{[17]}$. The TNF- a ELISA kit (Cat. No: EKHU-0110; LOT No: P20190329h) was purchased from Melsin Medical Co., Ltd., China.

\section{Statistical analysis}

Results obtained were subjected to statistical analysis using statistical package for social sciences (SPSS) version 23.0, SPSS Inc. Chicago, Illinois, USA. All parameters were expressed as mean \pm standard deviation (SD). The student ' $\mathrm{t}$ ' test was the tool of choice in comparing means. Values were statistically significant at $\mathrm{p} \leqslant 0.05$ or 0.001 and presented on tables and charts.

\section{Results}

A total of 92 serum samples from adults between the ages of 30-75 years were analyzed. The samples consisted of $28(30.43 \%)$ cases of HIV subjects on therapy, $18(19.57 \%)$ cases of HIV 
subjects not on therapy and $46(50 \%)$ apparently healthy subjects which served as control subjects.

Table 1 shows the mean \pm SD of CD4+T cells and TNF- a for the HIV subjects and control groups. There was a significant decrease when CD4+T cells in HIV subjects were compared with control group at $\mathrm{p}<0.001$. Table 2 shows the mean $\pm \mathrm{SD}$ of CD4+T cells and TNF- a of HIV subjects under treatment using different antiretroviral drugs. CD4+T cells and TNF- a did not show significant decrease when HIV subjects using abacavir+zidovudine was compared with those on tenofovir and zidovudine+lamivudine at $\mathrm{p}<0.05$.

Figure 1 shows the mean level of CD4+ T cells and TNF- $\alpha$ in HIV positive subject into different age groups. The chart shows that the mean level of CD4+ $\mathrm{T}$ cells and TNF- a are higher in HIV subjects within the age group 40-49 and 70-79 than the other age groups.

Figure 2 shows the mean levels of the parameters based on gender The chart showed that both TNF- $\alpha$ and CD4+T cells are both increased in male than in female.

Table 1: CD4+T cells and TNF- $\alpha$ in HIV positive subjects and control subjects

\begin{tabular}{lllll}
\hline Variables & $\begin{array}{l}\text { HIV seropositive } \\
\text { subjects } \\
\mathrm{N}=46\end{array}$ & $\begin{array}{l}\text { Control } \\
\mathrm{N}=46\end{array}$ & T values & P values \\
\hline $\begin{array}{l}\mathrm{CD} 4+\mathrm{T} \text { cells } \\
\left(\mathrm{cell} / \mathrm{s} / \mathrm{mm}^{3}\right)\end{array}$ & $638.22 \pm 12.77$ & $798.70 \pm 25.71$ & -5.591 & $0.001^{* *}$ \\
& & & & \\
$\begin{array}{l}\mathrm{TNF} \text { alpha } \\
(\mathrm{pg} / \mathrm{mL})\end{array}$ & $7.85 \pm 1.47$ & $13.25 \pm 1.42$ & -2.644 & $0.010^{*}$ \\
& & & &
\end{tabular}

**----- significant at $\mathrm{p}<0.001$

*----- significant at $\mathrm{p}<0.05$

Table 2: CD4+T cells and TNF- $\alpha$ in HIV positive subjects based on drugs used

\begin{tabular}{lccccc}
\hline Variables & $\begin{array}{l}\text { Abacavir+ } \\
\text { Zidovudine } \\
\mathrm{N}=9\end{array}$ & $\mathrm{Tenofovir}$ & $\begin{array}{l}\text { Zidovudine+ } \\
\text { Lamivudine } \\
\mathrm{N}=7\end{array}$ & F values & P values \\
\hline $\begin{array}{l}\text { CD4+Tcells } \\
\left(\text { cells } / \mathrm{mm}^{3}\right)\end{array}$ & $690 \pm 20.18$ & $693.83 \pm 17$ & $681.14 \pm 18.59$ & 0.103 & 0.902 \\
$\begin{array}{l}\mathrm{TNF} \text { alpha } \\
(\mathrm{pg} / \mathrm{mL})\end{array}$ & $13.57 \pm 6.50$ & $8.17 \pm 1.49$ & $4.23 \pm 1.60$ & 1.276 & 0.297 \\
& & & & & \\
\hline
\end{tabular}




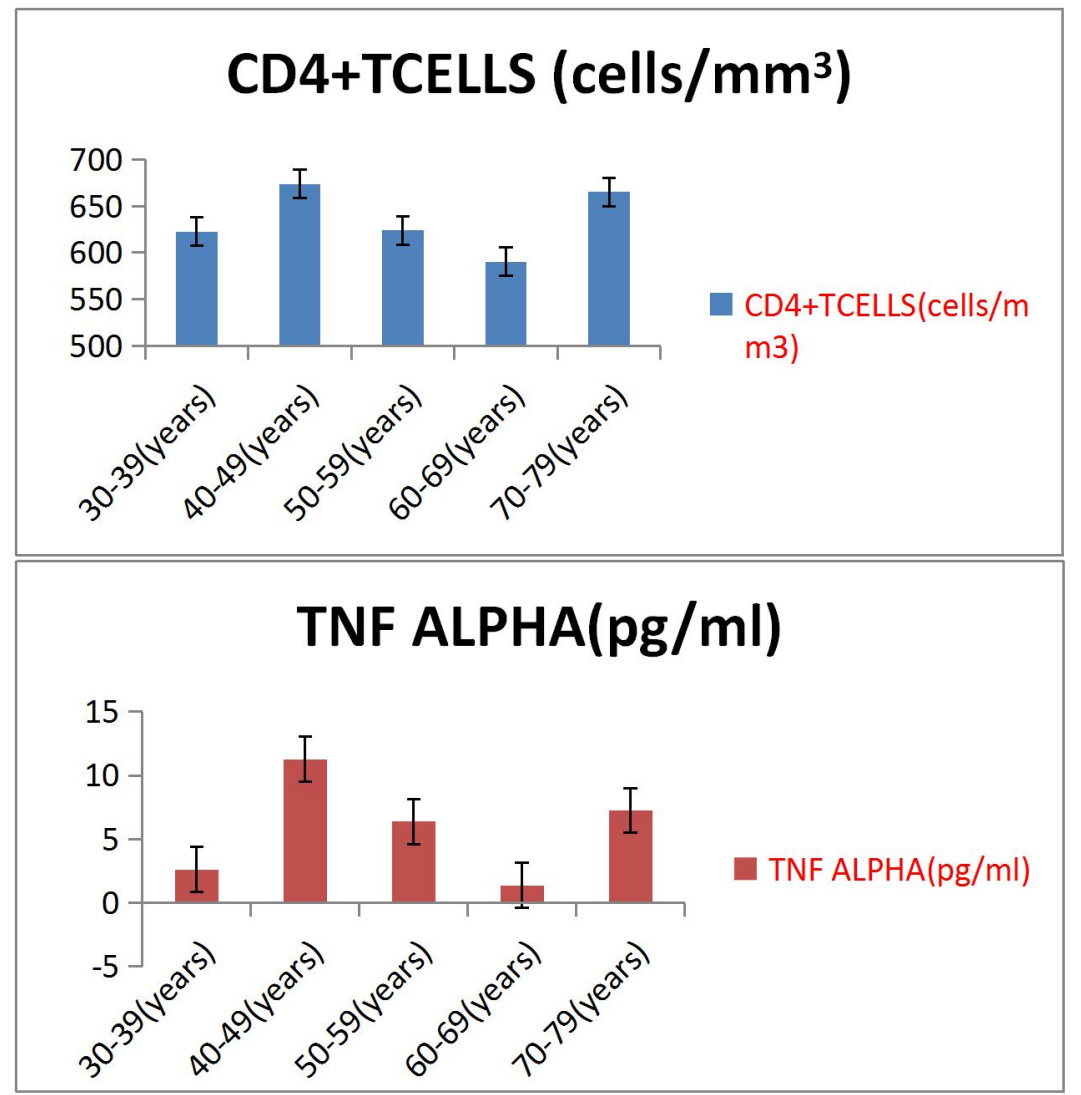

Figure 1: CD4+T cells and TNF alpha in HIV positive subjects according to age group

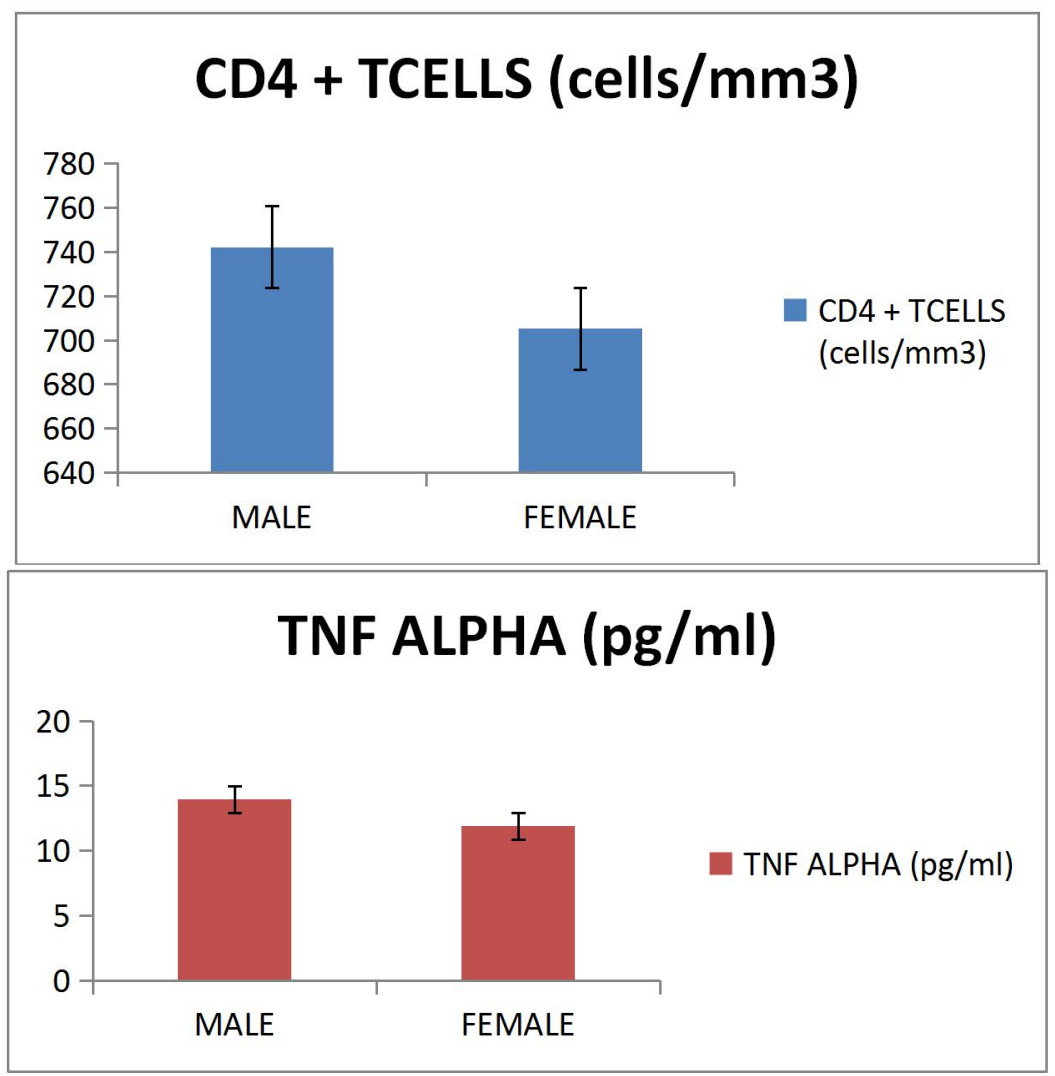

Figure 2: CD4+ T cells and TNF alpha in HIV seropositive subjects according to gender 


\section{Discussion}

In this study there was a significant decrease in CD4+ $\mathrm{T}$ Cells in HIV positive patients when compared with control. It has been shown that the level of CD4+T Cells are reduced in the HIV positive subjects as a result of progress in the HIV infection which is in line with other studies which observed that a progression in HIV infection is directly related to the rate at which CD4+ $\mathrm{T}$ Cells are lost ${ }^{[18,19]}$. There was significant decrease in the level of TNF- a in HIV subjects compared with control. The reason for this may be as a result of loss of immunity which was detected in the HIV subjects characterized by decreased CD4+T cells compared with the control. TNF- $a$ and its super family is considered as central mediators of a broad range of biological activities. These activities encompass beneficial effects for the host in inflammation and in protective immune responses against a variety of infectious pathogens ${ }^{[20]}$. However, other reports showed that TNF- a is associated with severity and progression of HIV related diseases including cognitive impairment and that it could be a potential inflammatory marker for disease monitoring ${ }^{[21,22]}$.

The level of CD4+T cells and TNF- a according to antiretroviral therapy were also compared. There was no significant difference between tenofovir (TDF) and zidovudine regimen (AZT) in regards to virologic response and this supports the work where it was observed that there was no significant difference between TDF and AZT in regards to virologic response ${ }^{[23]}$. However, another study observed that tenofovir treatment yielded a higher median increase in CD4 $+\mathrm{T}$ cell absolute count compared to zidovudine treatment and immune recovery than zidovudine based highly active antiretroviral therapy (HAART) but equipotent in virologic suppression ${ }^{[24]}$. The TNF- a did not also show significant difference which supports the study where the drugs used did not affect TNF- a and thus could not cause inflammation ${ }^{[25]}$. Also, the mean level of CD4+ T cells are seen to be higher in those taking tenofovir regimen than that of zidovudine which supports the study which showed that tenofovir treatment yielded a higher increase in CD4+ T cells compared with zidovudine treatment ${ }^{[24]}$. However, TNF- a level is not elevated in tenofovir compared with zidovudine regimen which supports the fact that the levels of pro inflammatory cytokines are not affected by ART ${ }^{[26]}$.

There was increased level of CD4+T cells and TNF- $\alpha$ in age group 40-49 and 70-79. The reason may be due to the time each of the age groups commenced the use of drugs. Also, TNF- a may remain unaltered when HIV replication has been well controlled by ART for a long time ${ }^{[27]}$.

CD4+T cells were seen to be higher in male subjects compared with female and this is in agreement with the research done where it was observed that CD4+ $\mathrm{T}$ cells in women tend to decrease over time than in men ${ }^{[28]}$.

\section{Conclusion}

This study showed significant decrease in the levels of CD4+ T cells and TNF- $\alpha$ in HIV positive subjects compared with control. Although the study did not observe significant increase in TNF- $a$, the study concluded that the decreased level of CD4+ T cells could create an opportunity for opportunistic infections. Presence of these opportunistic infections could cause inflammation and in turn raise the level of TNF- a in the body. Therefore, there is need to monitor these parameters during HIV infection.

\section{Acknowledgement}

The Authors acknowledge the support of the staff members in ART Clinic and Laboratory of Federal Medical Center, Ido Ekiti, Ekiti State for their support during sample collection.

\section{Conflict of interest}

The authors declare that there is no conflict of interest whatsoever.

\section{References}

1 Cohen MS, Chen YQ, McCauley M. Antiretroviral therapy for the prevention of 
HIV-1 transmission. New England Journal of Medicine, 2016, 375,830 - 839.

2 Malik S, Özkaya SG, Mikael I, Anders W, Joakim E, Patrick M. "Genetic characterization of human immunodeficiency virus type 1 transmission in the Middle East and North African. Heliyon, 2016, 3 (7),352.

3 Rodger AJ et al. Risk of HIV transmission through condomless sex in serodifferent gay couples with the HIV-positive partner taking suppressive antiretroviral therapy (PARTNER): Final results of a multicentre, prospective, observational study. Lancet 2019. DOI:doi.org/10.1016/S0140-6736(19)30418-0

4 Mabuka J, Nduati R, Odem-Davis K, Peterson D, Overbaugh J. HIV-specific antibodies capable of ADCC are common in breastmilk and are associated with reduced risk of transmission in women with high viral loads. PLoS Pathog 2012; 8(6): e1002739 DOI: 10.1371/journal.ppat.1002739

5 Hahn, Robert A. Inhorn, Claire,M eds. Anthropology and public health : bridging differences in culture and society (2nd ed.). Oxford: Oxford University Press. 2009; 449. ISBN 978-0-19-5374643. OCLC 192042314.

6 Centers for Disease Control (CDC). Kaposi's sarcoma and Pneumocystis pneumonia among homosexual men--New York City and California. (MMWR); Morbidity and Mortality Weekly Report, 1981; 30:305.

7 Murrell, D. Facts about HIV: Life expectancy and long-term outlook. 2019;Retrieved: https:/www.healthline.com/h ealth/hiv-aids/life-expectancy [assessed on 7/8/2019]

8 Nazli A, Chan O, Dobson-Belaire WN, Ouellet M, Tremblay MJ, Gray-Owen SD, Arsenault AL, Kaushic C. Exposure to HIV-1 directly impairs mucosal epithelial barrier integrity allowing microbial translocation. PLoS Pathog 2010; 6(4): e1000852 [PMID: 20386714 PMCID: PMC2851733 DOI: 10.1371/journal.ppat.1000852]

9 Nwosu FC, Avershina E, Wilson R, Rudi K. Gut Microbiota in HIV Infection: Implication for Disease Progression and Management.
Gastroenterol Res Pract 2014; 2014: 803185 DOI: $\underline{10.1155 / 2014 / 803185}$

10 Bandera A, Ferrario G, Saresella M, Marventano I, Soria A, Zanini F, Sabbatini F, Airoldi M, Marchetti G, Franzetti F, Trabattoni $\mathrm{D}$, Clerici M, Gori A. CD4+ T cell depletion, immune activation and increased production of regulatory $\mathrm{T}$ cells in the thymus of HIVinfected individuals. PLoS One 2010; 5(5): e10788 DOI: $10.1371 /$ journal.pone.0010788

11 Kumar A, Abbas W, Herbein G. TNF and TNF Receptor Superfamily Members in HIV infection: New Cellular Targets for Therapy? Mediators Inflamm. 2013; 2013: 484378.

12 Tyor WR, Glass JD, Griffin JW, Becker PS, McArthur JC, Bezman L, Griffin DE. Cytokine expression in the brain during the acquired immunodeficiency syndrome. Ann Neurol, 1992, 31;349 - 360.

13 Weissman D, Poli G, Fauci AS. Interleukin 10 blocks HIV replication in macrophages by inhibiting the autocrine loop of tumor necrosis factor alpha and interleukin 6 induction of virus. AIDS Res Hum Retroviruses, 1994, 10;1199 - 1206.

14 Poli G. Laureate ESCI award for excellence in clinical science 1999. Cytokines and the human immunodeficiency virus: from bench to bedside. European Society for Clinical Investigation. Eur J Clin Invest 1999; 29(8): 723-732 DOI: $10.1046 / \mathrm{j} .1365-$ 2362.1999.00525.x

15 Kumar A, Coquard L, Herbein G Targeting TNF-Alpha in HIV-1 Infection. Curr Drug Targets. 2016,17(1);15-22.

16 Ferrucci L, Bandinelli S,Benvenutri E,Di Lorio A, Macchi C, Harris TB. Subsystems contributing to the decline in ability to walk: bridging the gap between epidermology and geriatric practice in the in CHIANTI study. Journal of American Geriatric society, 2000,48;1618-1625.

17 David Barnett, Brooke Walker, Allan Landay, Thomas N. Denny. CD4 immunophenotyping in HIV infection. National Review Microbiology, 2008, 6(11);7-15.

18 Steven G. Deeks, Christina M. R. Kitchen, Lea Liu, Hua Guo, Ron Gascon, Amy B. Narváez, Peter Hunt, Jeffrey N. Martin, James O. Kahn, 
Jay Levy, Michael S. McGrath and Frederick M. Hecht. Immune activation set point during early HIV infection predicts subsequent CD4+ T-cell changes independent of viral load. Blood, 2004, 104;942-947.

19 Oluboyo A O, Okogun , GRA, Duru, LAD, Oluboyo,BO, Emenike EF. Obasikene,CN. Pattern Of Blood Pressure,CD4+ T Cells Count And Some Cardiac Enzymes In HIV Seropositive Subjects. Journal of Biomedical Investigation, 2006, 4(2);37-41.

20 Dembic Z. Cytokines Important for Growth and/or Development of Cells of the Immune System. The Cytokines of the Immune System, 2015; 263-281

21 Brabers NA, Nottet HS. Role of the proinflammatory cytokines TNF-alpha and IL1 beta in HIV-associated dementia. Eur J Clin Invest 2006; 36(7): 447-458 [PMID: 16796601 DOI: $10.1111 / \mathrm{j} .1365-2362.2006 .01657 . \mathrm{x}]$

22 Vieira, BJ; Blembeel, AS; Dorneles, GP; Cé, J; Peres, A; Coelho,JC; Mello, AS. Analyses of IL-6, IL-10, IL-17A, INF- $\gamma$ and TNF- $\alpha$ Cytokines in Diseases of Mucopolysaccharidosis Type I and Mucopolysaccharidoses Type VI. American Journal of Biomedical Research, 2019,7(1); 3-8. doi: 10.12691/ajbr-7-1-2

23 Spaulding A, Rutherford GW, Siegfried N. Tenofovir or zidovudine in three-drug combination therapy with one nucleoside reverse transcriptase inhibitor and one nonnucleoside reverse transcriptase inhibitor for initial treatment of HIV infection in antiretroviral-naive individuals. Cochrane Database Syst Rev 2010(10): CD008740 DOI: $\underline{10.1002 / 14651858 . C D 008740}$
24 Badii, VS, Buabeng,KO, Poku, TA, Forkuo,AD, Boamah, BB, Arhin, SM, Kpewou, DE. International Journal of Chronic Diseases, 2018. DOI:https://doi.org/10.1155/2018/3702740

25 Martinez E, Larrousse $M$, Podzamczer D, Perez I, Gutierrez F, Lonca M, Barragan P, Deulofeu R, Casamitjana R, Mallolas J, Pich J, Gatell JM, Team BS. Abacavir-based therapy does not affect biological mechanisms associated with cardiovascular dysfunction. AIDS 2010; 24(3): F1-9 [PMID: 20009917 DOI: 10.1097/QAD.0b013e32833562c5]

26 Enumah, CL, Nwauche,CA, Okerengwo,A. Anaemia and Pro-inflammatory Cytokines in Human Immunodeficiency Virus Infection. International Journal of Immunology, 2016, 4 (3); 13-18

27 Rosado I, De Pablo-Bernal RSE, Ruiz-Mateos E, Dominguez-Molina B, Alvarez-Ríos AI, Carrillo-Vico A, De La Rosa R, Delgado J, Muñoz-Fernández MA, Leal M. TNF- a levels in HIV-infected patients after long-term suppressive cART persist as high as in elderly, HIV-uninfected subjects. Journal of Antimicrobial Chemotherapy, 2014, 69(11); 3041-3046

DOI:https://doi.org/10.1093/jac/dku263

28 Anastos, K, Gange,S, Lau,B, Weiser,B, Detels,R, Giorgi, J, Mardolick, J, Cohen, M, Phair,J. Association of race and gender with hiv-1 rna levels and immunologic progression. Journal of acquired immune deficiency syndromes, 2000, 24(3); 218-226. 